\title{
153. On Malignolipin. XIII
}

\section{Effect of Anti-Malignolipin Rat Serum on the Survival Period of Rats Bearing Yoshida Sarcoma*)}

\author{
By Takekazu Kôsaki, Keishi Muraki, Noriko Nagayasu, \\ and Shinya NAKAGAWA \\ Department of Biochemistry, \\ Mie Prefectural University, School of Medicine, Tsu \\ (Comm. by Y. Kuno, M.J.A., Nov. 12, 1962)
}

It had previously been reported ${ }^{1)}$ that Yoshida sarcoma cells were destroyed within a short period of time on exposure to antimalignolipin rat serum in vitro, but that the antiserum caused almost no change in the survival period of rats bearing Yoshida sarcoma. To disclose the reason of the discrepancy between the in vivo and in vitro experiment, and also to determine the possibility of destroying malignant cells in the living body by the application of anti-malignolipin serum, further studies were made.

Normal male rats of Wistar strain, and of about $100 \mathrm{~g}$ in body weight, were used in the experiment. The anti-malignolipin rat serum was prepared in the way reported previously.2

A group of rats inoculated intraperitoneally with $9 \times 10^{6}$ Yoshida sarcoma cells were daily given subcutaneous injections of $0.1-0.3 \mathrm{ml}$ of anti-malignolipin rat serum, beginning from the 5th day after the inoculation, and continuing until all rats had died. The other group of rats similarly inoculated with Yoshida sarcoma cells were given injections of normal rat serum in place of antiserum. As shown in the table, no significant difference could be found between the average survival days of the two groups.

Since, in the above-reported experiment the amount of antibody that would contact the malignant cells seemed to be too small, a further experiment was planned. Rats were inoculated with a smaller number of Yoshida sarcoma cells. Immediately afterwards, while the number of sarcoma cells was smallest, a larger amount of antiserum was injected intraperitoneally into these same rats. Results are shown in the figure. Rats of the control group, to which $0.2 \mathrm{ml}$ of physiological saline solution had been given instead of the antiserum,

*) In part, aided by Grant No. CA-04795 from the National Institute of Health, United States Public Health Service, and also by Grants from the Ministry of Welfare, Shionogi Co., and Upjohn Co.

1) Kôsaki, T., et al.: Proc. Japan Acad., 36, 527 (1960). (1961).

2) Kôsaki, T., et al.: Proc. Japan Acad., 36, 524 (1960): Mie Med. J., 11, 67 


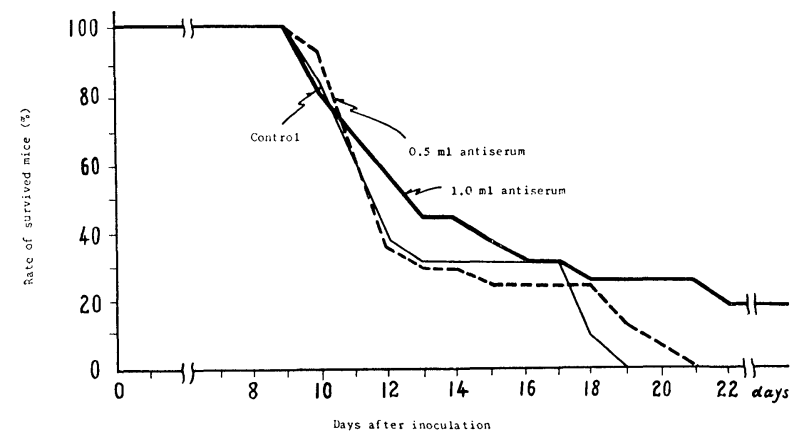

Rate of survived rats after intraperitoneal inoculation of Yoshida sarcoma. $4.5 \times 10^{6}$ of Yoshida sarcoma cells inoculated. Anti-malignolipin rat serum (complement fixing titer $\times 128$ ) given intraperitoneally, immediately after the inoculation.

$\{1.0 \mathrm{ml}$ given: 16 cases

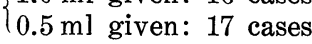

Control rats (13 cases): $1.0 \mathrm{ml}$ of physiological saline solution given intraperitoneally, immediately after the inoculation.

Average survival period of rats after intraperitoneal inoculation of Yoshida sarcoma

\begin{tabular}{c|c|c|c|c|c|c|}
\hline \multirow{2}{*}{$\begin{array}{c}\text { Number of } \\
\text { cells inocu- } \\
\text { lated }\left(\times 10^{6}\right)\end{array}$} & \multicolumn{2}{|c|}{ Antiserum } & $\begin{array}{c}\text { Interval } \\
\text { between } \\
\text { inoculation } \\
\text { ment fix- } \\
\text { ing titer }\end{array}$ & $\begin{array}{c}\text { Amount } \\
\text { given } \\
(\mathrm{ml})\end{array}$ & $\begin{array}{c}\text { Number } \\
\text { of } \\
\text { animals } \\
\text { injection(days) }\end{array}$ & \multicolumn{2}{|c|}{$\begin{array}{c}\text { Average survival period } \\
\text { of time (days) }\end{array}$} \\
\hline 8 & $\times 80$ & 0.1 & 6 & 11 & 10.4 & $9.3(11)$ \\
\hline 9 & $\times 320$ & 0.1 & 4 & 10 & 10.2 & 9.8 \\
9 & $\prime \prime$ & 0.3 & 4 & 10 & 11.0 & \\
\hline
\end{tabular}

Anti-malignolipin rat serum or normal rat serum given subcutaneously, and daily until death. In bracket: number of control animals.

died within 19 days after the inoculation, the average survival period being 12.4 days. Rats that had been given $0.5 \mathrm{ml}$ of antiserum died within 21 days after the inoculation, the average survival period being 12.6 days. There was no significant difference between the two groups. However, three of the 16 rats given $1.0 \mathrm{ml}$ of antiserum survived more than 4 months, the average survival period being 39.2 days.

In short, the antibody againt malignolipin was demonstrated to destroy Yoshida sarcoma cells in the bodies of rats when an amount of antibody larger than a certain value per number of malignant cells was introduced into the rats. Results indicate that there is a lower limit to the amount of antibody which will destroy sarcoma cells, and that an amount of antibody below that limit has almost no effect on the survival period of tumor-bearing rats, even after having been applied several times. Results suggest, therefore, that anti-malignolipin serum might be used in a living body to destroy malignant cells completely, if a high-titered antiserum could be obtained. 